\title{
De Nederlandse regering in Londen en de 'Vrije Fransen'
}

\author{
A. F. MANNING
}

De Nederlandse regering in Londen heeft in de zomer van 1940 serieus rekening gehouden met de vredeskansen die er volgens velen waren. Beraad in eigen kring bewijst dat. Het blijkt duidelijk uit de Nederlands-Engelse betrekkingen en uit de relatie tot het bewind van Pétain te Vichy. Ook de Nederlandse houding ten opzichte van Italië is daarvan een voorbeeld. Pas in het najaar van 1940 zocht Nederland de status van volwaardig en zelfstandig bondgenoot van de Engelsen. Die lichtten de Nederlanders overigens naar hun zin te weinig in en betrokken hen niet in de oorlogvoering, preciezer gezegd in het militaire beraad en politieke beleid. Sinds oktober wilde de regering Gerbrandy daar wel in gekend worden en zij wees de Engelsen op het economisch potentieel van Nederlands-Indië en op de belangrijke handels- en oorlogsvloot die aan de Duitsers ontkomen was. Nederland, zo luidde de redenering, diende als een bondgenoot van betekenis en als een middle power te worden beschouwd, te onderscheiden van allerlei andere regeringen in Londense ballingschap. In het voorjaar van 1942, na de verovering van Indië door Japan, verzwakte de Nederlandse positie maar verdween de pretentie niet. Men kan niet zeggen dat de Engelsen en later de Amerikanen deze zienswijze van de Nederlandse regering wilden volgen. $\mathrm{Zij}$ schatten de gevechtskracht van de Nederlanders in Indië niet hoog en zij konden of wilden zich niet hecht aan Nederland binden voor de verdediging van de koloniën. In het algemeen werd de Nederlandse buitenlandse politiek tijdens de Tweede Wereldoorlog gekenmerkt door zorgvuldig koopmanschap en diplomatieke voorzichtigheid. Ze was afgestemd op de Engelse politiek en hield in tweede instantie sterk rekening met de Amerikaanse gevoelens.

De Fransen waren op 10 mei 1940 bondgenoot geworden in de strijd tegen Duitsland. Enige militaire samenwerking kwam tot stand en Franse troepen hebben in die meidagen in Zuidnederland gevochten. Nederland onderhield na de wapenstilstand van Frankrijk met Duitsland tot begin september 1940 vanuit Londen betrekkingen met de regering-Pétain. Die relaties zijn na Duitse pressie op Vichy verbroken. Daarna ontwikkelde zich langzamerhand het contact met de groep rond generaal De Gaulle. Aanvankelijk was het niet meer dan een comité waartegenover 
zich andere Franse groeperingen stelden. Velen beschouwden De Gaulle en de zijnen als een club politieke heethoofden, die temidden van de min of meer machteloze regeringen-in-ballingschap verkeerde. Het comité van De Gaulle werd pas in de zomer van 1944 als voorlopige regering erkend; door de Grote Drie gebeurde dat pas diep in het najaar.

In deze studie zal worden nagegaan hoe de relatie tussen de Nederlandse regering en de Vrije Fransen van De Gaulle zich heeft ontwikkeld en waardoor die verhouding werd bepaald ${ }^{1}$.

Vooraf dient iets gezegd te worden over de diplomatieke betrekkingen tussen Nederland en de Franse Republiek, die op 6 september 1940 werden beëindigd. Toen de militaire katastrofe duidelijk was geworden en onderhandelingen over een wapenstilstand op gang kwamen, deelde minister Van Kleffens aan de Nederlandse gezant jhr. dr. J. Loudon, die op dat moment in Limoges verbleef, mee dat hij contact diende te bewaren met de Franse regering wanneer er geen wapenstilstand tot stand zou komen. Indien er wel een wapenstilstand gesloten zou worden, moest hij voeling houden met Sir Ronald Hugh Campbell, de Britse ambassadeur, en een overeenkomstige gedragslijn volgen in afwachting van nadere instructies. Zo dacht Van Kleffens er op 20 juni over. Twee weken later, op 3 juli, liet Loudon vanuit La Bourboule via Bern weten dat de Britse ambassadeur was vertrokken. Dat was al in de nacht van 22 op 23 juni gebeurd nadat Campbell de Franse regering te Bordeaux had verweten dat zij Engeland in de steek had gelaten en dat zij had geweigerd de Franse vloot naar veiliger havens te sturen ${ }^{2}$. De Nederlandse gezant was de Franse regering naar Vichy gevolgd. Omdat hij daar geen onderkomen kon vinden, bleef hij voorlopig in Hôtel du Pare in La Bourboule. Op 8 juli berichtte Van Kleffens hem dat hij bij de Franse regering moest blijven. Loudon was er inmiddels in geslaagd een bezoek aan Vichy te brengen, waar hij de woede had ervaren over de Britse actie tegen de Franse vloot.

Van Kleffens hield Loudon voor dat de Frans-Britse betrekkingen door andere factoren werden bepaald dan de Nederlands-Franse en dat voortzetting van de oorlog door Nederland niet in tegenspraak was met het onderhouden van betrekkingen met de Franse regering, die een wapenstilstand met de Duitsers had gesloten. Lou-

1. Voor dit opstel werd het Londens Archief van het Ministerie van Buitenlandse Zaken gebruikt, onder andere het Geheim Archief DZ/GA R. Frankrijk (Comité); ibidem, N. Frankrijk; ibidem, GII Frankrijk 27 en 34; GA II (6) en IV (2) Brandkast. Voorts werden geraadpleegd de Notulen Ministerraad 1940-1945 en de collectie-Van Kleffens in het Algemeen Rijksarchief te 's-Gravenhage en het dagboek van Mr. E. N. van Kleffens dat in het Rijksinstituut voor Oorlogsdocumentatie te Amsterdam berust. Aan drs. A. E. Kersten ben ik veel dank verschuldigd voor het attenderen op en verzamelen van verspreid liggende stukken.

2. Llewellyn Woodward, British Foreign Policy in the Second World War (Londen, 1970) I, 305 vlg. en 401 vlg. De betrekkingen waren verder verslechterd door de mogelijkheid die de Engelsen aan De Gaulle gaven op 23 juni een radiotoespraak te houden en het kwam tot een nagenoeg volledige breuk door de Engelse acties tegen de Franse vloot op 3 juli bij Oran. 
don moest duidelijk maken dat de Fransen Nederland en Engeland niet over één kam moest scheren. Secretaris-generaal Charles Roux deelde de Nederlandse gezant eind augustus mee dat de Duitsers tijdens de onderhandelingen over de nadere uitwerking van de wapenstilstandsvoorwaarden in Wiesbaden hadden geëist dat de Franse regering de diplomatieke betrekkingen zou verbreken met die landen die door Duitsland waren bezet. Loudon begaf zich op 25 augustus naar de Franse minister van Buitenlandse Zaken, P. Baudouin, die dat bericht bevestigde. Baudouin voegde er aan toe dat het zeer pijnlijk was dat Frankrijk onder Duitse druk deze stap moest zetten. Loudon protesteerde, maar dat hielp natuurlijk niet en hij telegrafeerde vervolgens naar Londen dat de Franse regering het wel op prijs zou stellen indien de Franse gezant bij de Nederlandse regering, baron de Vitrolles, in zijn functie gehandhaafd kon blijven ${ }^{3}$. Vichy verbrak op 5 september om 24.00 uur de betrekkingen met Nederland ${ }^{4}$. De Nederlandse regering beschouwde het als een tijdelijke maatregel, als een schorsing van de diplomatieke betrekkingen die van zo kort mogelijke duur moest zijn.

De positie van de Nederlandse regering in Londen was op dat moment niet sterk. Haar prestige was klein en haar mogelijkheden in ballingschap waren zeer beperkt. Invloedrijke Engelse kringen hadden geen hoge dunk van de mogelijkheden om West- en Oost-Indië te verdedigen en taxeerden de politieke wil om de oorlog energiek door te zetten ook niet hoog. De Amerikanen wilden geen wapens leveren om Indië te verdedigen. Voorts was het de Nederlandse regering een doorn in het oog dat de Verenigde Staten en Engeland haar gezag niet volledig erkenden toen zij probeerde het Nederlands particulier bezit in het buitenland te beheren. De Nederlandse regering kon het moeilijk verteren dat ze weinig of geen informatie kreeg over de internering van een aantal Nederlanders in Engeland en zij was bovendien verbolgen over de Engelse argwaan ten opzichte van het KLM-personeel in het

3. A. F. Manning en A. E. Kersten, ed., Documenten betreffende de buitenlandse politiek van Nederland, Periode C (1940-1945). RGP, Grote Serie, CLVII (Den Haag, 1976) I, 374-375. Van Kleffens vroeg op 3 september de consulaire vertegenwoordigingen onaangetast te laten. In augustus en september 1941 constateerde men dat het Franse consulaat-generaal in Batavia zonder betekenis was geworden: alle consulaire posten werden omgezet in offices français zolang de offices néerlandais in Frankrijk open zouden blijven. De Nederlandse consulaten in Indo-China werden gesloten. Baron de Vitrolles werd door de Nederlandse regering als niet meer in functie beschouwd omdat de betrekkingen geschorst waren. Zelf ontplooide hij geen activiteiten omdat hij geen schriftelijke instructies had. Vitrolles kwam op 1 oktober 1940 bij een verkeersongeluk in Londen om het leven. De Nederlandse regering deelde dat aan zijn echtgenote en zijn zoon mede en liet een uitvaartdienst houden.

4. Jhr. dr. J. Loudon (1866-1955) vertegenwoordigde Nederland sinds 1919 in Parijs. De Franse regering had Loudon gevraagd in het land te blijven. Van Kleffens ging daarmee akkoord, verleende de gezant twee maanden verlof met verblijfsvergoeding en stelde hem op 12 maart 1941 op disponibiliteit met ingang van 1 november 1940. Het besluit werd pas zo laat genomen, omdat Van Kleffens 'den loop der gebeurtenissen wenschte af te wachten'. Tijdens de oorlog woonde Loudon te Cannes. 
Caraïbisch gebied. In Nederlandse kringen bestond in het algemeen de vrees dat de Engelsen op naoorlogse economische voordelen uit waren.

Buiten Engeland waren er niet minder problemen. Elk ogenblik dreigde er een bericht van de Spaanse regering te komen dat de gezant in Madrid zijn koffers kon pakken, omdat men niets te maken wenste te hebben met Londense ballingen. Er was bepaald reden voor dat de Nederlandse regering haar prestige wilde opvijzelen: de pretentie een middle power te zijn en de realiteit stemden niet met elkaar overeen.

De positie van generaal De Gaulle en zijn groep was uiteraard nog zwakker. In juni 1940 kreeg hij van bijna niemand steun, niet van de Franse vluchtelingen in Londen en evenmin vanuit de koloniën, want geen enkele gouverneur reageerde op zijn oproep. De Gaulle nam krachtig stelling tegen de regering te Vichy, die het 'ware' Frankrijk niet kon vertegenwoordigen en daarom een illegitiem regime moest heten. Voor de die-hards die vanuit Engeland door wilden vechten was zo'n politieke keuze aantrekkelijk, maar voor anderen zeer zeker niet: defaitisten, attentistes en diplomaten wensten Vichy niet te verketteren. De Gaulle trachtte echter overal erkenning te krijgen en betrokken te raken bij de beslissingen van de geallieerden. De Engelse regering gaf hem eerst enige speelruimte door het 'Comité de la France libre' de dag na zijn oprichting te erkennen. Dat gebeurde op 22 juni. In die tijd had Churchill zich reeds afgekeerd van de regering te Vichy en speelde hij met de gedachte de vorming van een Franse regering in ballingschap aan te moedigen. Er waren toen drie Franse oud-premiers in Londen, maar géén van hen schaarde zich achter De Gaulle. Op 7 augustus 1940 erkende de Britse premier de Franse generaal als 'chef de tous les Français libres', waar die zich ook zouden inzetten voor de verdediging van de geallieerde $\mathrm{zaak}^{5}$.

De Gaulle bemerkte al gauw dat er van gezamenlijke oorlogvoering eigenlijk geen sprake was en dat de Engelse regering een nauwe samenwerking met de Verenigde Staten voorop stelde. Dat land moest in de oorlog betrokken worden en het feit dat Washington diplomatieke betrekkingen onderhield met Vichy was op dat moment voor Engeland minder belangrijk. Uiteraard stemden de buitenlanders in Londen hun beleid eveneens af op de Amerikaanse en Engelse houding en daarom kostte het De Gaulle veel moeite de politieke ladder te beklimmen. Hij wilde in de Franse koloniën invloed verwerven en tussen alle rivalen probeerde hij zichzelf als leider van de Vrije Fransen te pousseren. De Engelsen hadden het comité erkend maar zij voelden er niets voor het tot een voorlopige regering uit te laten groeien. De eerste anderhalfjaar van de oorlog hadden de Engelsen De Gaulle's troepen

5. Het Comité beschikte over een strijdmacht die op grond van een verklaring van 7 augustus 1940 samen met de geallieerden de strijd tegen Duitsland voortzette. Eind oktober sloten zich enkele koloniën bij het Comité aan, onder anderen Tchaad, de Nieuwe Hebriden, Kameroun en Frans Equatoriaal Afrika. Zie verder M. Flory, Le statut international des gouvernements réfugiés et le cas de la France libre (Parijs, 1967); Neville Waites, ed., Troubled Neighbours (Londen, 1971). Hierin zijn vooral de artikelen van Ph. Bell en K. Sainsbury van belang. 


\section{A.F. MANNING}

weliswaar nodig, maar zij wensten zelf het opperbevel over die manschappen te voeren. Bovendien hield Londen rekening met een politieke bekering van Vichy. Zo bleef De Gaulle voor de Engelsen de vertegenwoordiger van een groep Fransen, niet van de Vrije Fransen. Ook toen De Gaulle in september 1941 een stap verder ging en de 'Pouvoirs publics de la France libre' organiseerde terwijl hij zichzelf 'President du comité national' noemde, wensten de Engelsen zich uitdrukkelijk op een afstand te houden ${ }^{6}$. Ruim een jaar later hadden de landingen in Frans NoordAfrika plaats zonder dat De Gaulle er bij betrokken werd. Bovendien bleek steeds duidelijker dat de Amerikanen hem zo ver mogelijk buiten een toekomstige Franse regering wensten te houden ${ }^{7}$. Ook in 1943 en 1944 gaven de Engelsen voorrang aan goede betrekkingen tot de Verenigde Staten zodat de relatie tot de Vrije Fransen op het tweede plan bleef. De denkbeelden van De Gaulle cum suis over de positie van Frankrijk tijdens en na de oorlog betekenden voor de Engelsen dan ook een zware belasting.

Hoe stelde de Nederlandse regering in Londen zich formeel op tegenover De Gaulle? Minister Van Kleffens steunde zijn gezant in Ankara, toen deze eind september 1940 een vertegenwoordiger van De Gaulle afwimpelde. De man was, voorzien van een introductiebrief van de Engelse ambassade bij hem gekomen met het verzoek in het gebouw van het Nederlands gezantschap een bureau voor de Balkan te vestigen. De gezant stond niet onsympathiek tegenover de beweging van de Vrije Fransen, maar hij wenste geen moeilijkheden met de Turkse regering te krijgen en hij meende voorts dat de Syrische regering de inwilliging van een dergelijk verzoek zou aangrijpen om de enige weg voor de Nederlanders naar NederlandsOost-Indië (door de lucht) te versperren. Het risico te lopen dat het Nederlands belang geschaad werd was onjuist, meende hij. Toen ongeveer tezelfdertijd bleek dat een Nederlands oorlogschip op eigen initiatief De Gaulle met Franse militairen en afdelingen van het Vreemdelingen legioen van Dakar naar Frans Equatoriaal Afrika vervoerd had, kreeg de verantwoordelijke kapitein toch geen aanmerking. Het was Nederlandse schepen weliswaar verboden Franse havens binnen te lopen, maar dat verbod werd in oktober 1940 uit praktische overwegingen niet van toepassing verklaard op de vaart in West-Indië, en op de vaart van Suriname naar Cayenne. Het verbod werd later weer van kracht maar in december 1942 werd het

6. Eden schreef aan De Gaulle: 'In making this communication, I should make it clear that HM's Government are not to be regarded as expressing any views as to the various constitutional and juridical considerations contained in these enactments. In particular, ... .while HM's Government will be happy to maintain their representation with the Free French movement, they could not accredit a diplomatic representative accredited by you, since this would involve your recognition as the Head of a sovereign State' - Men bedenke dat in die tijd de betrekkingen tussen De Gaulle en Churchill gespannen waren.

7. De situatie was moeilijk omdat na de landingen de regering van Vichy en de groeperingen van Giraud en De Gaulle elk voor zichzelf het hoogste gezag claimden. 
opnieuw ingetrokken. De stemming binnen de kring van het kabinet en bij de $\mathrm{Ne}$ derlandse top-ambtenaren, die in Londen verbleven, was verdeeld. Velen beschouwden Pétain als een attentiste en behielden lange tijd enige sympathie voor de regering van de maarschalk. Minister Welter van Koloniën lijkt de interessantste vertegenwoordiger van deze richting te zijn. De beleidsambtenaren vreesden voorts dat een keuze vóór De Gaulle het Nederlandse aanzien bij Amerikanen en Engelsen zeer zou schaden. Ook zij schatten de kansen van De Gaulle niet hoog en zij meenden nog in november 1942 dat figuren als Giraud, Noguès en Catroux op het beslissende moment naar voren zouden treden ${ }^{8}$. De Gaulle had veel tijd nodig om voldoende prestige te krijgen. Hij bleef lange tijd slechts een lastige brigade-generaal die een paar weken staatssecretaris was geweest in het kabinet-Reynaud. De Nederlandse minister van Buitenlandse Zaken zag de status van De Gaulle en zijn 'comité national français' als volgt: 'Niet anders dan iemand die ook tegen Duitschland strijdt. Op dien voet is aanraking mogelijk'.

Op 24 september 1941 maakte De Gaulle bekend dat de 'Pouvoirs publics de la France libre' onder zijn leiding waren georganiseerd. Van Kleffens kreeg afschriften van correspondentie met de Belgische, Poolse en Tsjechische regeringen, waaruit bleek dat die regeringen De Gaulle's besluit erkenden. De Nederlandse regering ging nog niet zo ver en beperkte zich tot een formele bevestiging van ontvangst van de mededeling. Van Kleffens deelde zijn ambtgenoot van Justitie echter mee dat het wellicht tijd werd nader in contact te treden met de Vrije Franse Beweging. Van Kleffens merkte op 11 november 1941 tijdens de rondvraag in de vergadering van de ministerraad op dat hij de Fransen wilde terugschrijven in de trant van het Poolse antwoord, dat wil zeggen De Gaulle erkennen 'comme chef de tous les Français libres qui se rallient à lui pour continuer la lutte aux côtés des alliés'. Dat gebeurde in de eerste helft van december. De Nederlandse regering erkende bovendien paspoorten die door de Vrije Fransen werden uitgegeven. Al eerder had zij erin toegestemd dat schepen die onder gezag van het comité stonden een eigen vlag voerden in Nederlandse overzeese havens. De Fransen 'are so easy to please and so difficult to discourage', constateerde een Amerikaanse journalist in die tijd. Zij zonden opnieuw afschriften van brieven die aantoonden dat nog een aantal andere regeringen het comité had erkend. Een nieuw stadium volgde in april 1942 toen Maurice Dejean, 'commissaire national aux affaires étrangères', afschriften zond van zijn

8. Zie bijvoorbeeld Lamping aan P. Kerstens (minister van handel, nijverheid en scheepvaart) 17 november 1942, ARA Collectie Van Kleffens, 1940-1945-dossier VI/9. De Nederlandse kringen in Londen waren nogal ontsteld over wat zich in Noord-Afrika afspeelde, met name dat Darlan daar een rol van betekenis kon spelen en dat Eisenhower met deze Quisling een arrangement tot stand bracht: 'Men kan ons evengoed vragen met Mussert samen te werken'. Zie ook Notulen Ministerraad 8 december 1942.

9. Van Kleffens aan A. Loudon (gezant in Washington), 14 september 1940, DZ/GA R. Frankrijk (Comité). 


\section{A.F. MANNING}

correspondentie met Trygve Lie over het aangaan van diplomatieke betrekkingen met Noorwegen. In die maand nam ook de Nederlandse regering een beslissing. Er werden over en weer vertegenwoordigers benoemd, maar zonder volledige diplomatieke status omdat het comité niet als de officiële regering werd erkend. E. Star Busmann werd op 4 mei 1942 Nederlands vertegenwoordiger bij het 'comité national français' en De Gaulle benoemde Raymond Offroy in een zelfde functie bij de Nederlandse regering ${ }^{10}$.

Tot juni 1944 gebeurde er niet veel. Koningin Wilhelmina zond een telegram op Quatorze Juillet. Van Kleffens sprak of lunchte met deze en gene en stelde hooggeplaatste figuren van het comité aan de koningin voor. Op 10 juli 1944 introduceerde hij De Gaulle zelf bij de koningin. Die ontmoeting verliep uitstekend, vond Van Kleffens: 'De beide hoofdpersonen waren in goede vorm en schenen elkaar te waarderen'11. Inmiddels was het Londense comité sinds 3 juni 1943 opgegaan in een 'comité français de la libération nationale' met Algiers als zetel ${ }^{12}$. De Nederlandse regering die instemde met deze ontwikkeling had haar gezant te Tanger, F. Gerth van Wijk, met de vertegenwoordiging bij het comité belast. Hij reisde verschillende malen naar Algiers, waar P. J. Eekhout in zijn afwezigheid als vertegenwoordiger optrad. Beide heren hielden hun minister van Buitenlandse Zaken in Londen uitvoerig op de hoogte van alle moeilijkheden en intriges in Algiers: de twisten tussen de fracties van Giraud en De Gaulle, de corruptie en de baantjesjagerij, de 183 generaals en 23 admiraals (voor ieder schip één spotte men) van de groep-Giraud. Het onderwerp dat in de rapportage vanuit Algiers het uitvoerigst aan de orde kwam, was het feit dat de Verenigde Staten het comité niet erkenden. Trouwens ook de gezant in Washington schreef vaak over dit onderwerp. Hij wist te vertellen dat sommige Amerikaanse kringen de mogelijkheid niet uitsloten dat Pétain democratische hervormingen overwoog. De herhaalde mededeling dat admiraal Leahy, de laatste Amerikaanse vertegenwoordiger bij Pétain in Vichy, Roosevelt's belangrijkste adviseur voor Franse aangelegenheden was, vormde belangrijker nieuws. Leahy meende dat Pétain de enige Franse persoonlijkheid was met wie de Amerikanen in zee konden gaan. Hoewel de Nederlandse regering wist dat de Amerikanen moeilijk van dit standpunt zouden zijn af te brengen en dat Roosevelt een afkeer had van De Gaulle, groeide de overtuiging dat de eigenzinnige generaal de enige was die bij de bevrijding van Frankrijk het heft in handen kon nemen.

Toch bleef de Nederlandse regering in dat voorjaar en die voorzomer van 1944 zeer voorzichtig manoeuvreren. Toen Gerth van Wijk op 17 mei 1944 vanuit Algiers voorstelde het briefhoofd 'représentation néerlandaise auprès du gouverne-

10. Offroy werd later opgevolgd door J. Paris.

11. Dagboek Van Kleffens.

12. Dit Comité had als presidenten De Gaulle en Giraud en telde onder zijn leden Catroux, Massigli, Monnet, Philip en anderen. 
ment provisoire de la république française' op zijn schrijfpapier te plaatsen, kreeg hij te horen dat dat praematuur was. Van Kleffens wilde overigens wel een stap in deze richting zetten. Hij schreef op 20 mei aan de koningin dat het voor Nederland niet wenselijk zou zijn indien er in Frankrijk na de invasie wanordelijkheden zouden ontstaan. Misschien dat die niet zo gauw naar Nederland zouden overslaan, maar toch: West-Europa had rust nodig en dat was een Nederlands belang. Om die rust in Frankrijk te krijgen had men daar

een geschikt cristallisatiepunt noodig waaromheen de goed gezinden kunnen groepeeren; het wil voorkomen dat het bewind-De Gaulle het eenige is dat daarvoor in aanmerking komt; dat zoo zijnde schijnt het ons van belang dit bewind te verstevigen. De gematigde elementen zullen aldus beter in staat worden gesteld om het communistische element binnen zekere perken te houden.

Zo trad'een nieuw element in de Nederlandse overwegingen naar voren. Had men er tot dan toe vooral op gelet zich geen onnodige diplomatieke moeilijkheden op de hals te halen en in het spoor van de Engelsen en Amerikanen te blijven vanwege de bevrijding van moederland en koloniën waarvoor wij hulp nodig hadden, vanaf dat moment ging de vrees voor communistische activiteiten meetellen. Van Kleffens wist in die weken dat binnen de Engelse regering nog geen overeenstemming was bereikt over de erkenning van het comité: Eden wilde wel, maar Churchill was nog niet zo ver. Als de Engelsen evenwel bleven dralen en de Amerikanen bleven weigeren, zou de Sovjet-Unie wel eens eenzijdig tot erkenning kunnen overgaan. Overigens kon iedereen weten dat de verhouding tussen De Gaulle en de Amerikanen, in dit geval Eisenhower, op D-day en erna bijzonder slecht was.

Dejean, die de portefeuille van Buitenlandse Zaken beheerde, deelde op 8 juni formeel aan Van Kleffens mee dat het comité 2 juni j.1. besloten had zich als voorlopige regering te beschouwen. De Fransen gebruikten nu briefpapier met de vermelding 'Republique Française'. Aan Nederlandse kant volgde dadelijk druk beraad. De regering informeerde ijverig naar de te volgen gedragslijn van de Belgen en anderen. Men wist dat de tegenstand vanuit Washington onverminderd voortduurde. Hoewel de Nederlandse regering een jaar te voren bij de eersten was geweest die het 'comité français de la libération nationale' erkenden, wachtte ze in juni 1944 liever de beslissing van de grote mogendheden af. J. Paris, de Franse vertegenwoordiger bij de Nederlandse regering, kwam op 13 juni, enkele dagen na de ontmoeting van koningin Wilhelmina en De Gaulle, meedelen dat zijn voorlopige regering erkenning door de Nederlandse regering op prijs zou stellen opdat 'aldus het front van alle bezette landen beter tot zijn recht kwam'. Van Kleffens hield de boot af door Paris te vragen of het niet effectiever zou zijn dat zijn regering eerst bij de Amerikanen en Engelsen op erkenning aandrong en vervolgens bij de Nederlandse regering, zodat men in Washington en Londen zou kunnen vermoeden dat Nederland slechts hun besluit wilde sanctioneren. Die redenering werd enige weken 


\section{A.F. MANNING}

tegenover de Fransen gebruikt. In de vergadering van de ministerraad van 20 juni zei Van Kleffens dat erkenning van het comité als voorlopige regering royaal diende te geschieden of helemaal niet. In ieder geval niet op de geclausuleerde wijze waarop sommige andere landen deze kwestie hadden behandeld. De ministerraad liet de beslissing over aan de minister van Buitenlandse Zaken.

De situatie was moeilijk. De Noren erkenden het comité reeds als voorlopige regering en Nederland bleef talmen. De Nederlandse regering het zich door de Amerikanen tegenhouden. A. Loudon, de Nederlandse gezant in Washington, remde hard in deze zaak. Toen op 30 juni de erkenningsbrief al klaar lag en de Franse vertegenwoordiger bij Van Kleffens antichambreerde, las deze juist een binnengekomen codetelegram uit Washington. Daarin deelde Loudon mee dat hij even tevoren op het State Department te horen had gekregen dat Cordell Hull tevreden was over het feit dat Nederland inzake de erkenning van de Fransen niet overhaast handelde en verdere ontwikkelingen wilde afwachten: de Amerikanen achtten het immers niet uitgesloten dat andere groeperingen dan aanhangers van Vichy of van De Gaulle zich in Frankrijk zouden aandienen. Toen Loudon evenwel zei dat de Nederlandse regering op het punt stond het comité van De Gaulle als officiële Franse regering te erkennen, veranderde zijn zegsman op het State Department dadelijk van toon. Hij wees erop dat regeringen die dat hadden gedaan volgens instructie te horen kregen 'dat de tijd zou komen dat het Amerikaansche volk deze actie niet zou vergeten'. Er werd wat heen en weer gepraat en Loudon werd even alleen gelaten. Daarna zei men hem dat De Gaulle over een week naar Washington zou komen en men adviseerde de Nederlandse regering de resultaten van dat bezoek af te wachten. De bedreiging werd niet herhaald. Loudons advies aan Van Kleffens luidde inderdaad afwachten om te voorkomen dat er een verkoeling in de betrekkingen tot de Verenigde Staten zou ontstaan. Van Kleffens schreef Loudon in een Amice-brief dat het een 'narrow escape' was geweest.

Wat men U gezegd heeft bevalt ons [te weten hemzelf en zijn plaatsvervanger Michiels van Verduynen] slecht. Dit is dreigen. Het is nonsens, te zeggen dat het Amerikaansche volk den Belgen, Noren enz. kwalijk neemt dat deze reeds met de Vrije Franschen in zee zijn gegaan. De kwalijkneemsheid zit uitsluitend bij de heeren van het State Department zelf. En die willen ons thans blijkbaar naar hun hand zetten, smoezen onder elkaar, slikken dan de bedreigingen weer in, maar de opzet is volkomen duidelijk. $\mathrm{Nu}$ is er ook een andere zaak, en dat is onze positie.

Nederland had immers belang bij goede betrekkingen met zowel Washington als Parijs. Van Kleffens wilde de Amerikanen niet bruskeren, maar aan de andere kant dienden zij te begrijpen dat dit niet mocht gaan ten koste van de relatie met Frankrijk. Nederland kon niet blijven wachten totdat de Amerikanen eindelijk wisten hoe ze hun zaken met De Gaulle zouden regelen. Uiteindelijk was Van Kleffens bereid de erkenning nog even uit te stellen totdat De Gaulle Washington had be- 
zocht 'niet met genoegen maar in het belang van een juiste middenweg tusschen onze behoeften tegenover Frankrijk en de blijkbaar zoo scherp gevoelde verlangens van de Amerikanen'. Het zou Van Kleffens 'oprecht verheugen over korten tijd deze koorddanserij boven zooveel gevaarlijke klippen te kunnen beëindigen'.

Op 10 juli reageerde Loudon op deze beschouwing van Van Kleffens. Hij wees er op dat de antipathie tegenover De Gaulle niet zozeer in het State Department gezocht moest worden maar in het Witte Huis, hetgeen de zaak zo delicaat maakte. Een paar dagen later registreerde hij dat het bezoek van De Gaulle aan Washington het klimaat enigszins had verbeterd, hoewel het standpunt van de Amerikaanse regering ten aanzien van de erkenning van het comité niet wezenlijk was veranderd. Van Kleffens nam zich toen voor nog één week te wachten.

De knoop werd inderdaad op 21 juli doorgehakt. Vier dagen later ging een codetelegram uit naar de daarvoor in aanmerking komende posten:

Ik deel op 28 dezer Fransch vertegenwoordiger mede dat Nederlandsche regeering nota neemt van naamswijziging Comité en verheugd zal zijn met de voorlopige Regeering dezelfde betrekkingen te onderhouden als tot nu toe met Comité.

'Dejean vloeide over van dankbaarheid', tekende Van Kleffens op 28 juli aan. Onze erkenning kwam drie maanden eerder dan de formele erkenning door de Amerikanen, Engelsen, Canadezen en Russen.

De vraag die aan het begin van dit opstel werd gesteld, is gedeeltelijk beantwoord. We weten nu hoe de betrekkingen tussen de Nederlandse regering in Londen en de Vrije Fransen van Generaal De Gaulle zich op diplomatiek niveau hebben ontwikkeld. Inhoudelijk valt aan het vorenstaande niet veel toe te voegen. Er zijn wat kwesties over het handelsverkeer en over contacten tussen Nederlands West-Indië en de Franse koloniën in het Caraibisch gebied, maar erg belangrijk zijn die niet. Over blijft dan de vraag waardoor de Nederlands-Franse betrekkingen werden gekenmerkt. Ten eerste door klassieke voorzichtigheid. Er is een belangrijk voorschrift in de diplomatie: men moet moeilijkheden niet aantrekken en zich met juridische formuleringen veilig stellen. Die regel is door Nederland bepaald niet verwaarloosd, toen het positie moest kiezen tegenover De Gaulle's comité. Een telegrafische sympathiebetuiging van koningin Wilhelmina ter gelegenheid van de Franse nationale feestdag in 1942 was daarmee niet in strijd.

Vervolgens werd de relatie bepaald door de eigen positie. Tot oktober 1940 werden zoveel mogelijk deuren opengelaten. De oorlog kon beëindigd worden en waarom zou men dan met de Engelsen de banden met Vichy doorsnijden? De Nederlandse regering stelde zich pas in de nazomer dichter bij de Engelse bondgenoot op. De laatste bleek bereid te zijn het comité van De Gaulle te erkennen, maar de Nederlandse regering zou nog lange tijd nodig hebben om even ver te komen. Ze 
zag de fiasco's van De Gaulle bij Dakar, zijn moeilijkheden in het Midden-Oosten en het geruzie met andere groeperingen. Ze bemerkte hoe hij buiten spel werd gezet door de Engelsen en Amerikanen bij de bezetting van Madagascar en de landingen in Noord-Afrika. Daardoor besefte de Nederlandse regering dat het spel traag gespeeld moest worden. Ze wilde immers de betrekkingen met die bondgenoten die men nodig had voor de bevrijding van het moederland en de koloniën niet in gevaar brengen. Vandaar dat Van Kleffens eind september 1942 de Nederlandse vertegenwoordiger bij het comité nog eens tot voorzichtigheid aanspoorde en voorhield: 'In niets verschilt onze houding van de Engelsche...'.

$\mathrm{Na}$ het verlies van Nederlands Indië ging de Nederlandse regering in belangrijke mate rekening houden met de inzichten van de Amerikaanse regering. Die moest niets hebben van De Gaulle en zijn comité. Van Kleffens wist dat al vóór hij eind augustus 1942 Loudon aan Roosevelt liet zeggen dat de Vrije Fransen rond vertelden stellige aanwijzingen te hebben dat de Amerikanen een aanval op Dakar of Casablanca voorbereidden. Roosevelt was volgens de Nederlandse gezant erkentelijk voor het bericht en 'refereerde met een weinig vleiend gebaar aan de Vrije Franschen'. Loudon zond de Nederlandse regering in de laatste oorlogsjaren steeds uitvoerige informatie over de Amerikaanse openbare mening ten aanzien van de buitenlandse politiek en over het desbetreffende standpunt van het Witte Huis. Tot in het najaar van 1944 wees hij er voortdurend op hoe gevaarlijk het kon zijn indien de Nederlandse regering iets zou ondernemen dat afweek van de Amerikaanse politiek ten opzichte van de Vrije Fransen.

De houding van de Nederlandse regering werd voornamelijk bepaald door de koloniale kwestie. Vanaf 1942 wist de Nederlandse regering heel goed dat de koloniën na de oorlog moeilijkheden zouden opleveren. De Amerikanen zouden zich ongetwijfeld verzetten tegen het herstel van de koloniale imperia van Engeland, Frankrijk ${ }^{13}$ en Nederland. De voorbereiding van de beroemde redevoering van koningin Wilhelmina van december 1942 over de na-oorlogse status van Indië kostte niet voor niets zoveel tijd en correspondentie met het gezantschap in Washington. Evenmin was het toevallig dat een bericht van Star Busmann, de Nederlandse vertegenwoordiger bij het comité, onder de leden van de ministerraad circuleerde. Het bericht was op 14 november 1942 opgesteld en bevatte een beschouwing naar aanleiding van de landingen op de kust van Noord-Afrika. Roosevelt had de Bey van Tunis namelijk rechtstreeks gevraagd of de Amerikaanse troepen op zijn grondgebied mochten landen. Amerika negeerde dus de protectoraatsverhouding tussen Frankrijk en Tunis en ontkende door deze handelwijze het Franse gezag over Tunis. Star Busmann vervolgde:

13. Walter Lafeber in American Historical Review, LXXX (1975) 127 vlg. 
De stap van den President zou verder kunnen worden uitgelegd als een aanmoediging aan de inheemsche bevolking om zich zelfstandig te maken. Dit zou passen in de in Amerika voorkomende opvattingen omtrent de toekomst der koloniale gebieden.

Indien de Amerikanen bovendien nog bestuurlijke bevoegdheden zouden gaan uitoefenen met voorbijgaan van het Franse bestuur dan zou dat volgens Star Busmann wel eens een bedenkelijk precedent kunnen zijn 'met het oog op de herovering van Indië, en ik vraag mij af of het niet nuttig zal zijn over dit punt met de Engelschen in overleg te treden teneinde te vernemen of deze vrees gegrond is'. Of dit overleg ook heeft plaatsgevonden is thans niet bekend, evenmin of de vrees van Star Busmann door Van Kleffens werd gedeeld.

Nederland zou voor de bevrijding van het grondgebied in West Europa en ook voor Nederlands Oost-Indië afhankelijk zijn van de Engelse en Amerikaanse strijdkrachten. Wellicht was eveneens hulp voor het na-oorlogs herstel nodig. Die realistische overwegingen speelden aan Nederlandse zijde mee. Soms werd dit thema ook in de Amerikaanse pers bespeeld. Raymond Daniell deed dat in een byliner van de New York Times van 14 juni 1944 en veronderstelde dat Nederland de Verenigde Staten in een dergelijke situatie beslist niet voor het hoofd zou stoten. In de daaropvolgende weken werd in de Amerikaanse pers een discussie gevoerd over het al dan niet bezet houden van militaire bases in het Pacific gebied. Dat moest niet gezien worden als het overnemen van andermans koloniën maar als een veiligheidsmaatregel, meende men. Toen De Gaulle de onverkorte teruggave van de Franse bezittingen eiste, namen de Amerikanen, tot grote ontsteltenis van de voorlopige Franse regering in Algiers, daar geen notitie van. Van Kleffens meende op grond van een bericht van Loudon (28 juni) dat Roosevelt een herstel van het Franse imperium slechts onder voorbehoud zou toestaan. Deze mededeling over het veronderstelde Amerikaanse standpunt deed Van Kleffens op 10 juli 1944, juist op het moment dat hijzelf op advies van Loudon er in had toegestemd de reeds gereedgemaakte erkenningsbrief nog niet aan de Franse vertegenwoordiger te overhandigen. De 10e juli bezwoer Loudon Van Kleffens voorzichtig te zijn in verband met 'de voor ons zoo noodige samenwerking met de USA in het Verre Oosten. Ik meen derhalve zeer ernstig te moeten waarschuwen. Gevaren hier mogen niet onderschat worden'.

De Nederlandse regering ontwikkelde in de zomer van 1944 nog een nieuw argument om de regering van De Gaulle officieel te erkennen. Frankrijk zou in een bevrijd West-Europa uiteraard een belangrijke plaats innemen en het was ook een Nederlands belang dat eventuele wanordelijkheden in Frankrijk door een krachtig bewind zouden worden voorkomen ${ }^{14}$. Bij herhaling betoogde Van Kleffens - ook

14. Rond de jaarwisseling 1943-1944 had Van Kleffens aan de Nederlandse vertegenwoordiger in Algiers gevraagd hem de teksten van Franse regelingen betreffende hervestiging van het nationaal gezag bij terugkeer in Frankrijk te zenden. De vraag kan samenhangen met de voorbereidin- 


\section{A.F. MANNING}

op 20 mei 1944 tegenover de koningin - dat het voor Nederland zeer nadelig zou zijn indien in Frankrijk na de bevrijding wanorde zou ontstaan. Dat kon wel eens overslaan naar Nederland. De Gaulle leek de meest geschikte figuur om Frankrijk werkelijk te leiden. Ook de gematigde elementen zullen De Gaulle steunen, meende Van Kleffens, en het beoogde effect was 'het communistisch element binnen zekere perken te houden'. Onze gezant in Ottawa schreef op 16 juli dat De Gaulle tijdens zijn bezoek aldaar als zijn persoonlijke mening te kennen had gegeven 'dat het democratisch regime in Frankrijk niet hetzelfde zal zijn als het vóór den oorlog was'. Misschien klonk dat geruststellend voor wie heugenis had aan de krachteloze parlementaire democratie met haar snel opeenvolgende regeringen?

Van Kleffens merkte enkele maanden later op, na de Amerikaanse erkenning van De Gaulle's voorlopige regering, dat deze overwegingen in Washington op dit punt niet bestreden zouden worden. Van het Nederlandse gezantschap meldde men hem op 15 november 1944 dat de Amerikaanse regering inzag dat De Gaulle orde en rust bracht, terwijl de Maquis ongedisciplineerd optrad en de communisten een gevaar vormden. Sommige Amerikaanse kranten hoopten toen dat De Gaulle zich zou verzetten tegen de terugkeer van Maurice Thorez naar Frankrijk. Zij herinnerden zich de voordien niet serieus genomen bewering van Robert Murphy dat De Gaulle 'France's only barrier to communism' was.

Uiteraard dient men het geheel van voorbereidingen tot terugkeer van het normale burgerlijk gezag in Nederland na de bevrijding te onderzoeken voor men kan aangeven in hoeverre angst voor onrust en communistische agitatie de restauratieve tendenties bij wederopbouw en herstel hebben bepaald. Maar dat die tendenties er waren, is geen speculatie. Al met al kan men er begrip voor hebben dat de Nederlandse regering in die tijd de voorlopige regering-De Gaulle wilde erkennen. Dat was in de zomer van 1944 een reëel Nederlands belang, zoals het in een eerder stadium van belang was geweest niet vooraan te lopen maar scherp te letten op de houding van de Engelsen en later vooral op die van de Amerikanen.

gen die de Nederlandse regering zelf aan het treffen was, of met de overeenkomsten die de Amerikanen, met de Nederlanders, Belgen en Noren hadden getroffen terzake herstel van het burgerlijk bestuur. Het valt op dat ook in de volgende maanden vanuit Algiers materiaal werd gezonden over verkiezingen van Conseils municipaux en over de wijze waarop voor de Assemblée provisoire afgevaardigden zouden worden aangewezen en wat daarbij de rol van de politieke partijen en de résistance zou zijn. 


\title{
Een welgefundeerde, knappe en koele synthese
}

\author{
Een recensieartikel door J. A. Bornewasser
}

\section{E. H. Kossmann, De Lage Landen 1780-1940. Anderhalve eeuw Nederland en België (Amsterdam/BrusseJ: Elsevier, 1976, 618 blz., f45.-).}

Toen in 1815 het Koninkrijk der Nederlanden tot stand kwam, vloeiden twee geheel verscheiden ontwikkelingsprocessen ineen. In 1830, na ruim vijftien jaar gedwongen, gesublimeerde en niet eens zo perspectiefloze samenwoning verweten de ongelukkige partners elkaar het losgebarsten geweld; weldra zetten zij, een traumatische ervaring rijker, hun levensloop opnieuw gescheiden voort. Drukte het kortstondig samenzijn voor altijd zijn stempel op elk van beide landen, de uiteindelijke mislukking woog nog lang als een onaangename last op hun onderlinge verhouding. Waren Noord en Zuid niet in de eerste helft van de negentiende eeuw bijeen geweest, niemand zou waarschijnlijk op de idee gekomen zijn hun zo uiteenlopende levensgeschiedenissen in één boek te beschrijven.

Zelfs Pieter Geyl niet. Deze originele vormgever van de Groot-Nederlandse gedachte beperkte zich overigens uit beginsel tot het verhaal over de Nederlandstalige gebieden. Een ironische speling van het lot heeft bovendien gewild dat zijn Geschiedenis van de Nederlandse Stam bleef steken kort voor de periode waarin zij een nieuw hoogtepunt had kunnen bereiken. Het in 1959 verschenen deel III, dat voor nog geen halve eeuw zo'n vijfhonderd bladzijden nodig heeft, eindigt met 1798. Actualiteitsbewustzijn en theoretische reflectiedrang bleven het nadien bij de geëngageerde strijder Geyl winnen van de behoefte om de voleinding van zijn oorspronkelijke maar wat geforceerde gang door de geschiedenis te beproeven. Was trouwens het tot dan toe bereikte resultaat, hoe boeiend en leerzaam ook, van die aard dat daarmee de Groot-Nederlandse conceptie van aanwijsbare samenhangen en natuurnoodzakelijke convergentie haar vurig verlangde realisering had gevonden?

Een ander Groot-Nederlands voelend historicus, de onder invloed van F. C. Gerretson staande L. G. J. Verberne, schreef in het midden van de jaren dertig een gedegen en bevattelijke geschiedenis van de negentiende en vroeg-twintigste eeuw. Een niet minder ironische omstandigheid verhinderde dat hij aan een Groot-Nederlandse synthese zelfs maar serieus kon denken. Verberne's bijna klassiek geworden werk moest nu eenmaal verschijnen in het 'klein-Nederlandse' kader van de onder redactie van H. Brugmans opgezette Geschiedenis van Nederland, waarvan het de afsluitende, in 1938 uitgegeven delen VII en VIII uitmaakt. Toch lijkt het wel of de hiermee opgelegde beperking de auteur voor verzanding heeft behoed. Want toen na de Tweede Wereldoorlog een door hem zelf geredigeerde, wél Groot-Nederlands opgezette geschiedenis van beperkte omvang ging verschijnen, moest Verberne de moderne geschiedenis van de Zuidelijke Nederlanden door een Belgische vakgenoot in een apart deel laten beschrijven. Tussen theorie en praktijk van de Groot-Nederlandse geschiedschrijving lag een klaarblijkelijke kloof. 